\title{
Gaps in the protected area network for threatened Afrotropical
}

\section{birds}

\author{
H.M. De Klerka, ${ }^{*}$, J. Fjeldsa ${ }^{\circ}$ b, S. Blythc, N.D. Burgessd,e \\ aWestern Cape Nature Conservation Board-Scientific Services, Private Bag X5014, Stellenbosch, 7599, South Africa \\ * Corresponding author. Tel.: +27-21-866-8024; fax: +27-21-866-1523. \\ E-mail address: hdeklerk@cncjnk.wcape.gov.za (H.M. De Klerk). \\ bZoological Museum, University of Copenhagen, Universitetsparken 15, DK-2100 Copenhagen Ø, Denmark \\ cWorld Conservation Monitoring Centre, 219c Huntington Road, Cambridge CB3 ODL, UK \\ dWWF-US Conservation Science Programme, 1250 24th Street NW, Washington, DC 20037-1132, USA \\ eConservation Biology Group, Zoology Department, University of Cambridge, Downing Street, Cambridge CB2 3EJ, UK
}

Received 16 October 2002; received in revised form 26 August 2003; accepted 5 September 2003

Published as: Biological Conservation 117 (2004) 529-537

\begin{abstract}
Protected areas established for wildlife conservation (IUCN category I-VI protected areas) or for forest and watershed conservation (forest reserves) across mainland sub-Saharan Africa have high biodiversity values. However, they fail to cover over half of the 106 threatened bird species, and thus leave these vulnerable to extinction. An analysis of Red List bird species that are not represented in existing reserves indicates gaps in the current network of protected areas, namely: Mt. Cameroon-Bamenda highlands (Cameroon), the Angolan scarp (Angola), the Drakensberg Highlands (South Africa), the Highveld (South Africa), the Eastern Arc Mountains (Tanzania), the eastern African coastal forest mosaic (Kenya and Tanzania), the Albertine Rift (Uganda, Rwanda, Burundi, eastern Democratic Republic of Congo and western Tanzania), and the Ethiopian Highlands. The addition of Forest Reserves to the existing protected areas closes some of the reservation gaps for threatened birds in Africa. We suggest that these Forest Reserves should be included within official lists of protected areas, and that National forestry authorities be encouraged to manage these areas. Publication of scientific articles showing the conservation value of Forest Reserves is needed to raise local and international support and funding.
\end{abstract}

Keywords: Threatened birds; Afrotropical region; wildlife and forest reserves

\section{Introduction}

Protected area systems have generally been established on an opportunistic basis over the past 100 years, often on land not suitable for agriculture, with poor soils and with low human density (e.g. Siegfried, 1989; Pressey and Tully, 1994; Rebelo, 1994, Bruner et al., 2000; Scott et al., 2001). In Africa, most large protected areas are found in savanna habitats, where they typically support thriving populations of large mammal species on land that is generally unsuitable for human habitation (Balmford et al., 1992). To some extent the location and declaration of these reserves is a function of the history of the region. For example, human populations in eastern Africa fell from the early-middle 19th century until the early 20th century, due to a combination of introduced diseases, wars and slave trading (e.g. in East Africa-Kjekshus, 1977; Sutton, 1990). This resulted in some formerly farmed areas reverting to bush and wild animal populations increasing. The increase of the Tsetse fly and sleeping sickness that followed, rendered large areas of eastern and southern Africa uninhabitable. Some of these 'wilderness' areas, which had supported people only 100 years before, were proclaimed as protected areas to conserve their spectacular large mammal assemblages, for example the Selous Game Reserve established in southern Tanzania in 1922 (IUCN, 1998).

This ad hoc approach to the development of protected area networks is not adequate to safeguard the overall biological diversity of Africa. This is particularly true as the number of species threatened by extinction 
is increasing and the prevention of extinction is one of the most urgent challenges facing conservationists (Pimm et al., 1995). As a contribution to addressing this issue, we investigate how well the protected area network in Africa (IUCN, 1998; World Databases of Protected Areas) covers the distributions of bird species threatened by extinction (BirdLife International, 2000). Identification of gaps is only the first step in achieving conservation, and must be followed with advocacy (locally and internationally) and on the ground conservation work, in and outside formal conservation areas (as is currently done by the lead author's organisation, see www.cnc.org.za, and other organisations throughout the continent).

\section{Methods}

\subsection{Threatened species}

The threat status of Afrotropical bird species was assessed using the 2000 IUCN Red List (BirdLife International, 2000; Hilton-Taylor, 2000). The Red List provided a provisional list of 114 threatened species of birds in the Afrotropical biogeographical region (continental Africa south of 20_ N, termed sub-Saharan Africa, see de Klerk et al., 2002). Waterbirds breeding in the Afrotropics were included, but pelagic species (Spheniscus demersus) and non-breeding migrants (Crex crex, Vanellus gregarius, Falco naumanni, Aquila clanga, Aquila heliaca, Geronticus eremita, and Acrocephalus paludicola) were excluded. This gave a final list of 106 threatened bird species for analysis (Appendix). 2.2. Bird distribution data Since no continent-wide database exists of species represented inside existing reserves we used the largest existing database of African bird distributions, which has been developed by the Zoological Museum, University of Copenhagen, and the FitzPatrick Institute of African Ornithology, University of Cape Town, between 1994 and 2001 . In this database, birds are recorded in a 1_1 degree grid using WORLDMAP software (Williams, 1996; Burgess et al., 1998). Species maps are based on extensive literature reviews and considerable fieldwork, with no assessment of abundance across the species range, and using conservative interpolation to reduce collecting gaps. However, the distributions of rare, patchily distributed, or range-restricted species (which largely correspond to those classified as threatened) are based on confirmed records only. Coastal grid cells are included if more than a quarter of their area is covered by land.

\subsection{Protected area data}

Protected area data were obtained from the UNEPWorld Conservation Monitoring Centre (UNEP-WCMC, version 6.0 database of August 2003). This World Database of Protected Areas was the result of a major update of the protected areas database by UNEP-WCMC on behalf of IUCN World Commission on Protected Areas. This process has involved a consortium of conservation NGOs in addition to governments. This is the most current database for all protected areas available, but we are aware that this database is not absolutely complete.

\subsubsection{Reserved areas established for wildlife conservation}

In general these areas fall within the IUCN protected area categories I-IV (Scientific Reserve/Strict Nature

Reserve to Resource Reserve) and V-VI (Multiple-Use Management Area/Managed Resource Area) (IUCN, 1998), and are managed by various national and local conservation agencies (e.g. National Parks and the Western Cape Nature Conservation Board in South Africa, or the Kenya Wildlife Services in Kenya). We used protected area polygon data to calculate the percentage of each one-degree grid cell covered by these reserves, by overlaying a 1_1 degree grid (ca. 1225000 ha) on the protected area polygons projected using Lambert Azimuthal Equal Area projection (meridian=20 E; latitude=0), and then calculating the percentage of each grid cell covered by protected areas (Fig. 1) using ArcView 3.2a GIS software (ESRI, 2000).

\subsubsection{Reserved areas established for forest protection}


These areas fall outside the existing IUCN protected area categories, and are generally managed by Forest Department. Most of the forest reserves were either proclaimed for their water catchment functions, or for timber production, which in some cases is unsustainable. In some countries (especially in Eastern and Southern Africa) these reserves support natural forest and are as well protected as some of wildlife reserves (Game Reserves, Game Controlled Areas, etc.), but in other parts of Africa, forest reserves have been converted to industrial plantations of pine or Eucalyptus. We used the August 2003 version of the UNEPWCMC African protected areas database to calculate the percentage of each one-degree grid cell covered by forest reserves. It falls outside the scope of this paper to evaluate traditional African systems of protection (such as sacred groves, etc.) and community-based or privately managed wildlife management areas; these systems generally lack an official protected area status and have not been comprehensively mapped across the continent.

\subsubsection{Protected grid cells}

To assess the likelihood that threatened bird species are covered by the existing reserve network, we developed cut-off levels for amounts of protection and used these to assign grids as either 'protected' or 'unprotected' (sensu Williams et al., 1996a). We used four arbitrary cut-off levels as follows-10\% (10-24\%) of the area of a grid cell covered by protected areas, 25\% (25-32\%) covered, 33\% (33-49\%) covered, and finally $50 \%(50-100 \%)$ covered. By intersecting these cut-off levels with our calculations of the percentage of each one-degree grid in a wildlife or forest reserve, we developed different computer layers of 'protected' grids that could be compared against the distributions of threatened bird species.

\subsection{Analyses}

First, we determine how well wildlife reserves on their own and together with forest reserves covered the distribution of threatened bird species. This was calculated as the number of threatened bird species covered by each set of grid cells 'protected' by wildlife reserves and wildlife reserves plus forest reserves (hereafter wildlife plus forest reserves) at different percentage cut-offs. These results were compared against a near-minimum set of grids derived using complementarity (our 'idealised' solution). A rarity-based heuristic algorithm with redundancy back-checks was used to calculate the near-minimum set (Williams et al., 1996b), using WORLDMAP software (Williams, 1996). These methods have been shown to approximate the efficiency of more rigorous linear-programming branch-and-bound methods (e.g. Csuti et al., 1997). Nearminimum sets were calculated to represent all species in the data base at least once but up to five times where possible, since multiple representations of species increases the likelihood that viable populations are included in the minimum set (e.g. Williams et al., 1996b). Secondly, we calculated the number of grid cells, in addition to those 'protected' by wildlife and forest reserves, required to cover the distributions of threatened birds one to five times each, where possible. When converted into a percentage of the number of areas required by an idealised near-minimum set, this provides a measure of the additional effort required to achieve the goal of multiple representations of threatened bird species in areas not already 'protected'.

Thirdly, since we assume that conservation networks ought to be more efficient than randomly chosen sets of areas, we compared the sets of 'protected' grids with randomly chosen sets of one-degree grid cells to calculate the median representation of threatened bird species (and 95\% confidence limits about that median) across 1000 sets of each size (Burgess et al., 2002). We plotted the performance of the sets of grid cells 'protected' by wildlife and forest reserves at different cut-off levels, against the results of selecting similar numbers of grid cells randomly from the threatened bird species database. 


\section{Results}

Grid cells 'protected' by wildlife reserves cover between 99 and 403 grid cells when the percentage area coverage used to define a grid cell as protected is varied from 50 to 10\% (Table 1). At these extremes the 'protected' grid cells cover the distributions of between 20.7\%and 69.8\%of the threatened bird species (Fig.

2). The richness patterns of threatened bird species not represented in 'protected' grid cells defined at the $33 \%$ cut-off level are displayed in Fig. 3 ii. A visual comparison of Fig. $3 \mathrm{i}$ and ii suggest that species not covered at the $33 \%$ cut off are only a small fraction of all threatened species. This is because the protected area network covers mainly the widespread threatened species, while in fact the 71 species that were not covered (ca. 67\%) inhabit only a few cells, and are aggregated in small areas. These are primarily in the Mt. Cameroon-Bamenda highlands, the Angolan scarp, the Drakensberg Highlands, the Highveld, the Eastern Arc Mountains, coastal Kenya and Tanzania, the Albertine Rift, and the Ethiopian Highlands. To cover the distributions of all threatened bird species, additional grid cells need to be 'protected', ranging from an additional 22 cells to supplement the $10 \%$ 'protected' set to 34 cells for the $50 \%$ 'protected' set (for one representation per species) (Table 1).

Grid cells 'protected' by wildlife plus forest reserves cover between 117 and 522 grid cells as the percentage coverage cut-off is varied from 50 to $10 \%$ (Table 1). Threatened birds not covered by large areas of wildlife plus forest reserves occur in the Upper Guinea, Mt. Cameroon-Bamenda highlands, Angolan scarp, generally in South Africa, the Eastern Arc and Kenyan coast, Albertine Rift, and Ethiopian Highlands (Fig. 3 iii). In the case of South Africa, this is because their forest reserves are given an IUCN protected area code IV, and hence mapped here within the 'wildlife reserves'. Additional cells required to supplement the combined wildlife and forest reserves to represent all threatened bird species, range from 18 cells at the $10 \%$ protected area cut-off to 33 cells at the $50 \%$ protected area cut-off, for one representation per species (Table $1)$.

To represent all threatened bird species once in a minimum set chosen using complementarity requires 41 cells, and to represent them five times requires 166 cells (Table 1). When we consider the contribution of existing protected areas (by pre-selecting cells with a specified level of protection), the extra number of grid cells needed to represent all species increases proportionally with multiple representations of species. For example, if we consider which threatened bird species are represented by the 99 cells that have at least $50 \%$ of their area covered by wildlife reserves, 34 new grid-cells ( $82.9 \%$ of the original minimum set) are required to represent all threatened bird species once. For five representations per species, 154 new cells were needed (92.8\% of the original set) (Table 1). Similar patterns are observed, for wildlife plus forest reserves. Note that even though the smaller 'protected' sets (e.g. the 99 grid cells with $>50 \%$ wildlife reserve coverage) 'protect' fewer species than the larger 'protected' sets (e.g. the 117 grid cells with $>50 \%$ wildlife plus forest reserve coverage), smaller 'protected' sets allow the iterative algorithm more flexibility to place the remaining grid cells required to reach the representation target. They therefore do not require many more additional grid cells than the larger 'protected' sets.

In our comparison involving random selection of one-degree cells, the sets of 'protected' grid cells representing wildlife and wildlife plus forest reserves were relatively poor at representing the distribution of threatened bird species (Fig. 4) presumably because mixed and inefficient criteria were used to place existing protected areas (Humphries, personal communication). Those grid cells containing at least $10 \%$ of their area as wildlife plus Fig. 3. forest reserves perform the best in this test, being somewhat better than random selection (Fig. 4).

\section{Discussion}

4.1. Coverage of threatened bird distributions by the existing protected area network 
Even those grid cells containing large areas of wildlife or forest reserves do not cover the distributions of all threatened birds of the Afrotropical region. For instance approximately $36 \%$ of the threatened birds of the Afrotropical region occur in grid cells that have at least $25 \%$ of their area protected by wildlife reserves. The remaining $64 \%$ of threatened species, not covered by larger protected areas-Mt. Cameroon-Bamenda highlands, the Angolan scarp, the Drakensberg Highlands, the Highveld, the Eastern Arc Mountains and coastal Kenya/Tanzania, the Albertine Rift, and the Ethiopian Highlands-are concentrated in a few parts of Africa, mainly montane regions. These results support those of other studies (ICBP, 1992; Stattersfield et al., 1998; Fishpool and Evans, 2001; de Klerk et al., 2002), which suggest that efforts to prevent the extinction of threatened bird species should concentrate in these regions.

Unfortunately, recent research demonstrates that these same areas also possess high human populations and hence their habitats are under considerable pressure (e.g. Fjeldsa ${ }^{\circ}$ and Rahbek, 1998; Balmford et al., 2001). There is also a trend for reserves in such areas to be smaller and more isolated (Harcourt et al., 2001), which also explains why the grid cells in these areas are assessed here as poorly protected because they do not meet our minimum cut-off level of 10\% of a grid cell's area (ca. 122500 ha) within a protected area. The high human population densities in these regions have often existed for a long time and it has been assumed (Fjeldsa ${ }^{\circ}$ et al., 1997, 1999) that the specific conditions that allowed range-restricted bird species to survive periods of environmental stress also meant crop predictability, which facilitated the transition from life as hunter-gatherers to resident farming societies in the past, and the development of population centres. These areas with locally predictable climates are quite unlike the majority of African savanna areas, where national parks are often located (Fjeldsa ${ }^{\circ}$ et al., 1997; de Klerk et al., 2002). Bird species in some of these areas, for example in the Cameroon Highlands and the Eastern Arc Mountains (Burgess et al., 2001), seem able to live in relatively small habitat patches and hence we should not immediately conclude that they are doomed to extinction.

\subsection{Improvements in the protected area network}

In the past the reservation of protected areas was mainly focussed on establishing parks in areas with few people and high concentrations of large mammals (Balmford, 1992). This is reflected in the distribution of protected areas used for these analyses. Over the past decade, in particular as a response to the requirements of the Convention of Biological Diversity that was inaugurated at the UNCED conference of 1992 (UNCED, 1992), many nations looked again at their reserve networks to determine how well reserve networks cover species threatened with extinction. Some governments have started to fill in gaps in the types of habitats that were covered, and issues such as high levels of endemism and the conservation of rare and threatened species have been given greater consideration. This has resulted in the establishment of more protected areas in the montane forest, Mediterranean and desert biomes in recent years (Loucks et al., unpublished report to WWF). Examples are seen in the recent establishment of the Knersvlakte and Groenefontein Provincial Nature Reserves in the Western Cape Province of South Africa, and the Udzungwa Mountain National Park in Tanzania, specifically to protect highly threatened and poorly represented vegetation types with many rare, endemic and threatened species.

These newly declared parks and reserves were captured within the World Database of protected areas. The congress also provides an opportunity to upgrade the status of some African forest reserves so that they would feature on lists of officially protected areas and thus their contribution to biodiversity conservation would be recognised.

\section{Acknowledgements}

Helen de Klerk thanks the Foundation for Research Development for an airfare and the Western Cape Nature Conservation Board for time-off and subsistence to visit Jon Fjeldsa ${ }^{\circ}$ and Neil Burgess in 
Copenhagen to complete this paper. The Copenhagen Biosystematics Centre (COBICE) funded by the European Community supported Neil Burgess for his trip to Denmark. Paul Williams is thanked for the use of the Worldmap software, and ongoing support and discussion. UNEPWCMC are thanked for providing the protected areas data layer used here. Nick Lindenberg of the University of Cape Town, South Africa provided advice on the GIS projection. Louis A. Hanson compiled the databses used here and assisted in many other ways. The many people who have supported the development of our databases is presented elsewhere (see Burgess et al. 2002). Our thanks to Colby Loucks, Tom Allnutt, Lincoln Fishpool, and Chris Humphries for useful comments on thismanuscript. 
Appendix 1. List of the 106 terrestrial, residential species on the Afrotropical mainland afforded Red List status by Hilton-Taylor (2000). Taxonomy according Sibley and Monroe (1990). 
Egretta vinaceigula

Circus maurus

Gyps coprotheres

Sarothrura ayersii

Caprimulgus solala

Caprimulgus prigoginei

Phodilus prigoginei

Glaucidium albertinum

Scotopelia ussheri

Bubo vosseleri

Otus ireneae

Tauraco ruspolii

Tauraco bannermani

Schoutedenapus

schoutedeni

Agapornis nigrigenis

Agelastes meleagrides

Francolinus griseostriatus

Francolinus nahani

Francolinus harwoodi

Francolinus

camerunensis

Francolinus swierstrai

Francolinus ochropectus

Afropavo congensis

Xenoperdix

udzungwensis

Grus paradisea

Grus carunculatus

Torgos tracheliotus

Geronticus calvus

Cossypha heinrichi

Sheppardia lowei

Sheppardia montana

Sheppardia gabela

Sheppardia gunningi

Swynnertonia

swynnertoni

Muscicapa itombwensis
Muscicapa lendu

Melaenornis

annamarulae

Alethe choloensis

Zoothera guttata

Picathartes

gymnocephalus

Picathartes oreas

Platysteira laticincta

Prionops gabela

Prionops alberti

Malaconotus alius

Malaconotus gladiator

Telophorus kupeensis

Laniarius liberatus

Laniarius amboimensis

Laniarius brauni

Campephaga lobata

Pseudocalyptomena

graueri

Zavattariornis

stresemanni

Mirafra degodiensis

Mirafra ashi

Kupeornis gilberti

Turdoides hindei

Arcanator orostruthus

Macrosphenus pulitzeri

Eremomela turneri

Orthotomus moreaui

Chloropeta gracilirostris

Scepomycter winifredae

Bradypterus sylvaticus

Bradypterus graueri

Bradypterus grandis

Speirops

melanocephalus

Apalis karamojae

Apalis argentea
Apalis chariessa

Prinia leontica

Cisticola aberdare

Criniger olivaceus

Bleda eximia

Phyllastrephus leucolepis

Chlorocichla prigoginei

Hirundo megaensis

Cinnyricinclus femoralis

Hirundo atrocaerulea

Carduelis johannis

Serinus ankoberensis

Serinus flavigula

Estrilda poliopareia

Cryptospiza shelleyi

Malimbus ibadanensis

Malimbus ballmanni

Malimbus flavipes

Ploceus bannermani

Ploceus batesi

Ploceus subpersonatus

Ploceus burnieri

Ploceus golandi

Ploceus aureonucha

Ploceus nicolli

Anthus sokokensis

Anthus chloris

Anthus sharpei

Nectarinia rufipennis

Nectarinia rockefelleri

Anthreptes rubritorques

Anthreptes pallidigaster

Spizocorys fringillaris

Certhilauda burra

Heteromirafra ruddi

Heteromirafra archeri

Heteromirafra

sidamoensis 


\section{References}

Balmford, A., Leader-Williams, N., Green, M.J.B., 1992. The protected area system. In: Sayer, J.A., Harcourt, C.S., Collins, N.M. (Eds.), The Conservation Atlas of Tropical Forests: Africa. IUCN, Gland and Cambridge, pp. 69-80.

Balmford, A., Moore, J.L., Brooks, T., Burgess, N., Hansen, L.A., Williams, P., Rahbek, C., 2001. Conservation conflicts across Africa. Science 291, 2616-2619.

BirdLife International, 2000. Threatened Birds of the World. Lynx Edicions and BirdLife International, Barcelona and Cambridge, UK.

Burgess, N., Fjeldsa ${ }^{\circ}$, J., Rahbek, C., 1998. Mapping the distributions of Afrotropical vertebrate groups. Species 30, 16-17.

Burgess, N.D., Romdal, T.S., Rahner, M., 2001. Forest loss on the Ulugurus, Tanzania and the status of the Uluguru Bush Shrike Malconotus alius. Bulletin of the African Bird Club 8, 89-90.

Burgess, N.D., Rahbek, C., Larsen, F.W., Williams, P., Balmford, A., 2002. How much of the vertebrate diversity of sub-Saharan Africa is catered for by recent conservation proposals? Biological Conservation 107, 327-339.

Bruner, A., Gullison, R.E., Rice, R.E., Fonseca, G.A.B., 2000. Effectiveness of Parks in protecting tropical biodiversity. Science 291, 125-128.

Csuti, B., Polasky, S., Williams, P.H., Pressey, R.L., Camm, J.D., Kershaw, M., Kiester, A.R., Downs, B., Hamilton, R., Huso, M., Sahr, K., 1997. A comparison of reserve selection algorithms using data on terrestrial vertebrates in Oregon. Biological Conservation 80, 83-97.

de Klerk, H.M., Crowe, T.M., Fjeldsa ${ }^{\circ}$, J., Burgess, N.D., 2002. Patterns of species richness and narrow endemism of terrestrial bird species in the Afrotropical Region. Journal of Zoology (London) 256, 327342.

ESRI, 2000. ArcView 3.2a Software. Environmental Systems Research Institute, Redlands, CA.

Fishpool, L.D.C., Evans, M.I. (Eds.), 2001. Important bird areas in Africa and associated islands: priority sites for conservation. Bird-Life Conservation Series, no. 11. Pisces Publications and BirdLife International, Newbury and Cambridge, UK.

Fjeldsa $^{\circ}$, J., Ehrlich, F., Lambin, E., Prins, E., 1997. Are biodiversity "hotspots" correlated with current ecoclimatic stability? A pilot study using the NOAA-AVHRR remote sensing data. Biodiversity and Conservation 6, 401-422.

Fjeldsa $^{\circ}$, J., Rahbek, C., 1998. Continent-wide conservation priorities and diversification processes. In: Mace, G.M., Balmford, A., Ginsberg, J. (Eds.), Conservation in a Changing World. Cambridge University Press, Cambridge, pp. 139-160.

Fjeldsa $^{\circ}$, J., Lambin, E., Mertens, B., 1999. Correlation between endemism and local ecoclimatic stability documented by comparing Andean bird distributions and remotely sensed land surface data. Ecography 22, 63-78.

Harcourt, A.H., Parks, S.A., Woodroffe, R., 2001. Human density as an influence on species/area relationships: double jeopardy for small African reserves? Biodiversity and Conservation 10, 1011 1026.

Hilton-Taylor, C., 2000. 2000 IUCN Red List of Threatened Species. IUCN, Gland and Cambridge.

ICBP, 1992. Putting Biodiversity on the Map: Priority Area for Global Conservation. BirdLife International, Cambridge, UK. 
IUCN, 1998. 1997 United Nations List of Protected Areas. WCMC/IUCN, Cambridge and Gland.

Kjekshus, H.K., 1977. Ecological Control and Development in East Africa. Heinemann Educational Books, Nairobi.

Loucks, C., Burgess, N., Dinerstein, E. African Protected Areas: Supporting Myths or Living Truths? Unpublished Report (submitted to WWF-US).

Pimm, S.L., Russell, G.J., Gittleman, J.L., Brooks, T.M., 1995. The future of biodiversity. Science 269, 347350.

Pressey, R.L., Tully, S.L., 1994. The cost of ad hoc reservation: a case study in western New South Wales. Australian Journal of Ecology 19, 375-384.

Rebelo, A.G., 1994. Iterative selection procedures: centres of endemism and optimal placement of reserves. Strelitzia 1, 231-257.

Scott, J.M., Davis, F.W., McGhie, R.G., Wright, R.G., Groves, C., Estes, C., 2001. Nature reserves: do they capture the full range of America's biological diversity? Ecological Applications 11, 999-1007.

Sibley, C., 1990. G, Monroe, J.E., Distribution and Taxonomy of Birds of the World. Yale University Press, New Haven, CT.

Siegfried, W.R., 1989. Preservation of species in southern African nature reserves. In: Huntley, B.J. (Ed.), Biotic Diversity in Southern Africa: Concepts and Conservation. Oxford University Press, Cape Town, pp. 186-201.

Stattersfield, A.J., Crosby, M.J., Long, A.J., Wedge, D.C., 1998. Endemic bird areas of the world: priorities for biodiversity conservation. BirdLife Conservation Series no. 7. BirdLife International, Cambridge.

Sutton, J.E.G., 1990. A Thousand Years of East Africa. British Institute in Eastern Africa, Nairobi.

UNCED, 1992. The Rio United Nations Conference on Environment and Development: the Biodiversity Convention; Agenda 21 and the Rio Declaration. UNCED, Gland, Switzerland.

Williams, P.H., 1996. WORLDMAP 4.1 WINDOWS: Software and User Document 4.1. Privately distributed, London. Available from http://www.nhm.ac.uk/science/projects/worldmap.

Williams, P., Gibbons, D., Margules, C., Rebelo, A., Humphries, C., Pressey, R., 1996a. A comparison of richness hotspots, rarity hotspots, and complementary areas for conserving diversity of British birds. Conservation Biology 10, 155-174.

Williams, P.H., Prance, G.T., Humphries, C.J., Edwards, K.S., 1996b. Promise and problems in applying quantitative complementary areas for representing the diversity of some Neotropical plants (families Dichapetalaceae, Lecythidaceae, Caryocaraceae, Chrysobalanaceae and Proteaceae). Biological Journal of the Linnean Society 58, 125-157. 
Table 1

Numbers of 1_ grid cells in sub-Saharan Africa required to represent threatened bird species one to five times using WORLDMAP software (Williams et al., 1996b) to identify an idealised near-minimum set without reference to existing protected areas (a). Percentage of the idealised set (a) required to represent species in the database a specified number of times in addition to Wildlife Reserves alone (b), or Wildlife plus Forest Reserves (c)

Representation goal (no. of

No. grid cells required to represent threatened species a specified number of times

representations required per species) Idealised near-minimum set

$\begin{array}{rrrrr}1 & 2 & 3 & 4 & 5 \\ 41 & 77 & 107 & 141 & 166\end{array}$

Percentage of the idealised near-minimum set (and number of grid cells) required in addition to the protected areas network to achieve the representation goal.

\section{Wildlife reserves}

500 grid cells with $>10 \%$ area protected 266 grid cells with $>25 \%$ area protected 198 grid cells with $>33 \%$ area protected 109 grid cells with $>50 \%$ area protected

\section{Forest reserves}

169 grid cells with $>10 \%$ area protected 43 grid cells with $>25 \%$ area protected 26 grid cells with $>33 \%$ area protected $41.5(17) \quad 49.4(38) \quad 55.1$ (59) $55.3(78) \quad 56.0(93)$ $\begin{array}{lllll}65.9(27) & 70.1(54) & 74.8(80) & 76.6(108) & 77.1(128)\end{array}$ $75.6(31) 77.9(60) \quad 82.2(88) \quad 83.0(117) \quad 82.5(137)$ 80.5 (33) $85.7(66) \quad 88.8(95) \quad 89.4(126) \quad 90.4(150)$ 12 grid cells with $>50 \%$ area protected 


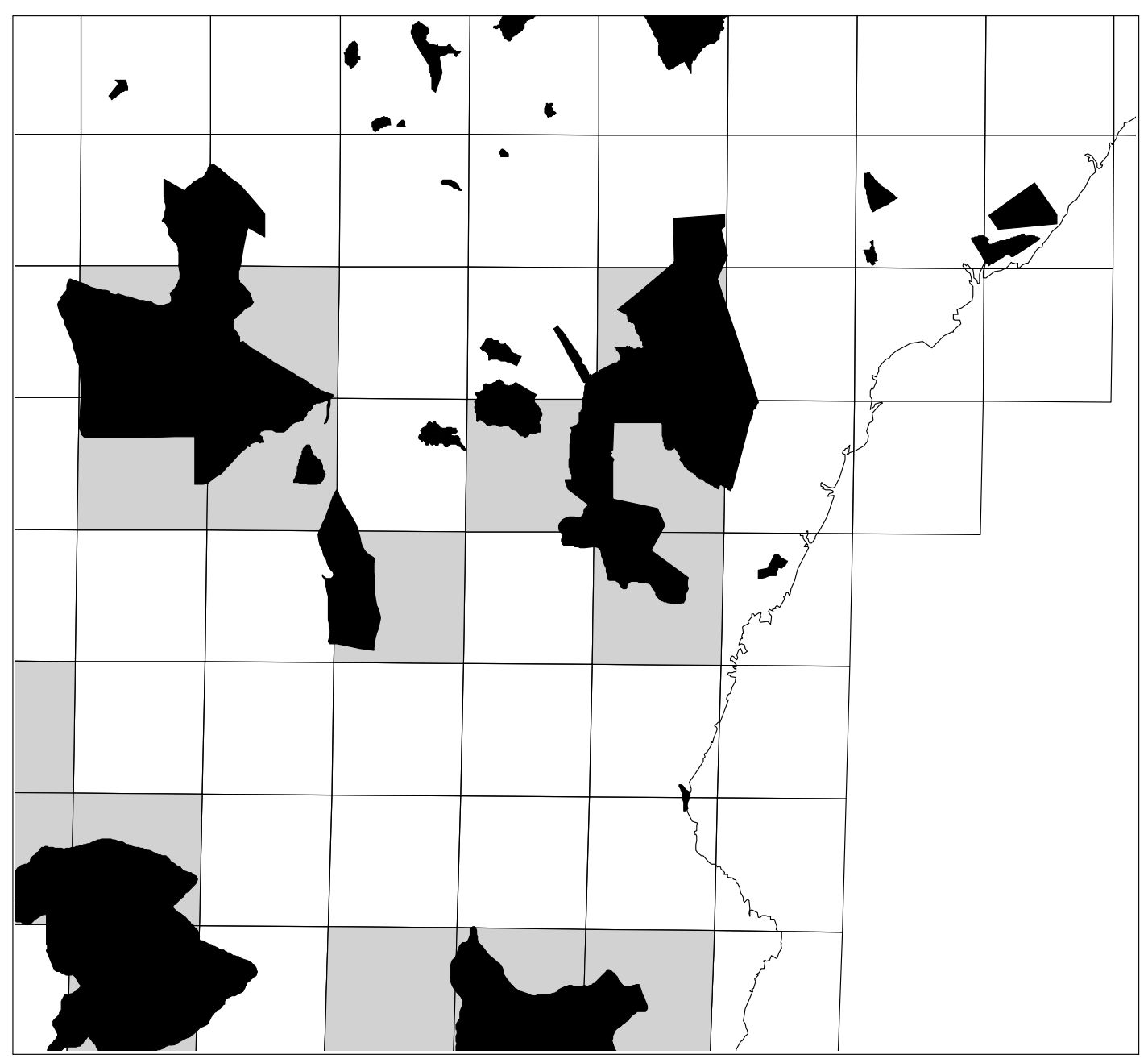

Fig. 1. Diagram of how the $1 \times 1$ degree grid was overlaid on the protected area polygons of Kenya and NE Tanzania, projected using Lambert Azimuthal Equal Area projection (meridian $=20 \mathrm{E}$; latitude $=0$ ), from where the percentage of each grid cell covered by protected areas could be calculated using ArcView 3.2a GIS software (ESRI, 2000). This diagram shows grid cells that have at least $25 \%$ of their surface area protected by wildlife reserves. 


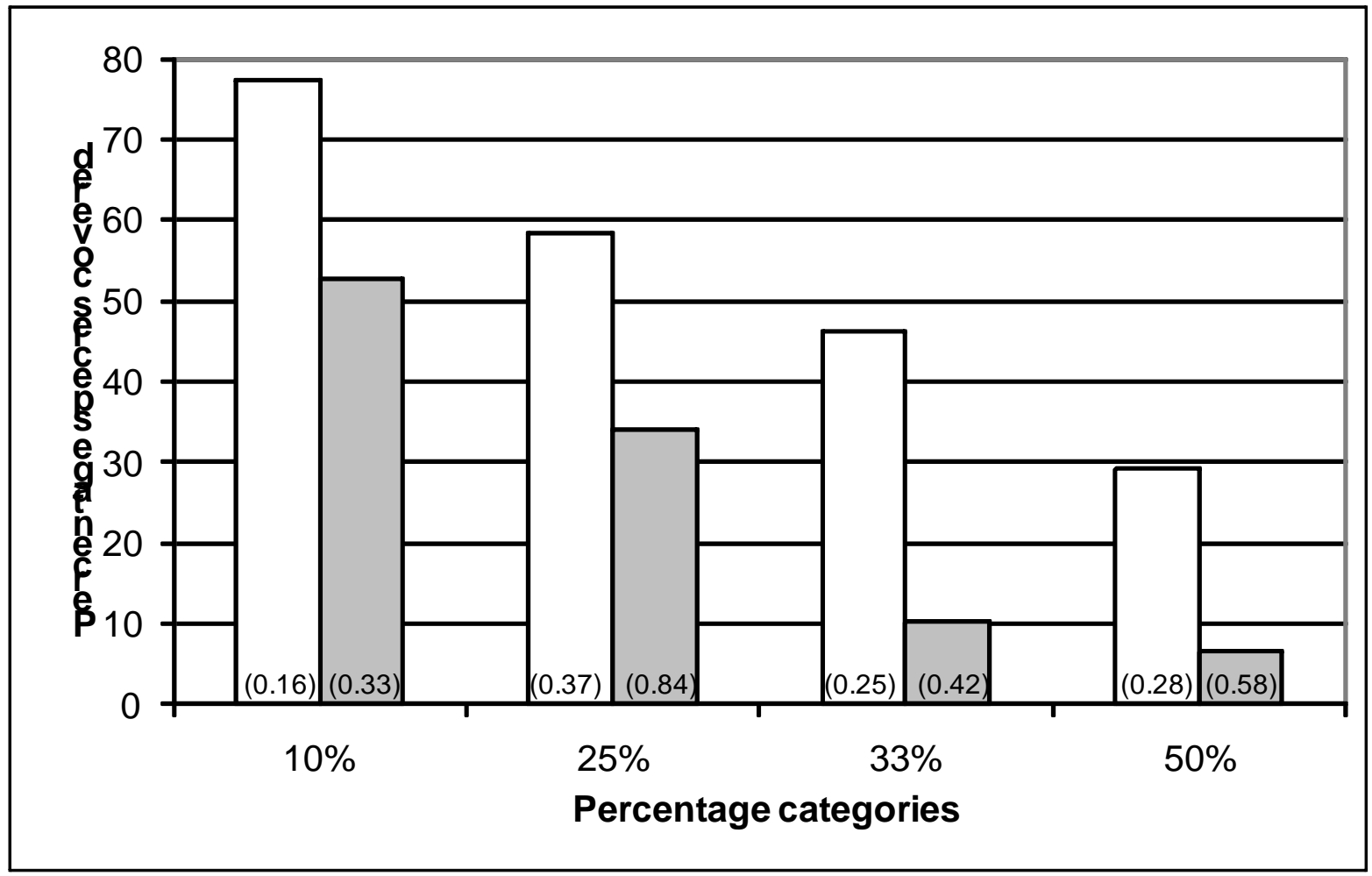

Fig. 2. Percentage of threatened bird species represented by grid cells defined as protected on the basis of wildlife reserves (white bars) and wildlife plus forest reserves (grey bars) covering four cut-off categories from 10 to $50 \%$ areal coverage. 
(i)

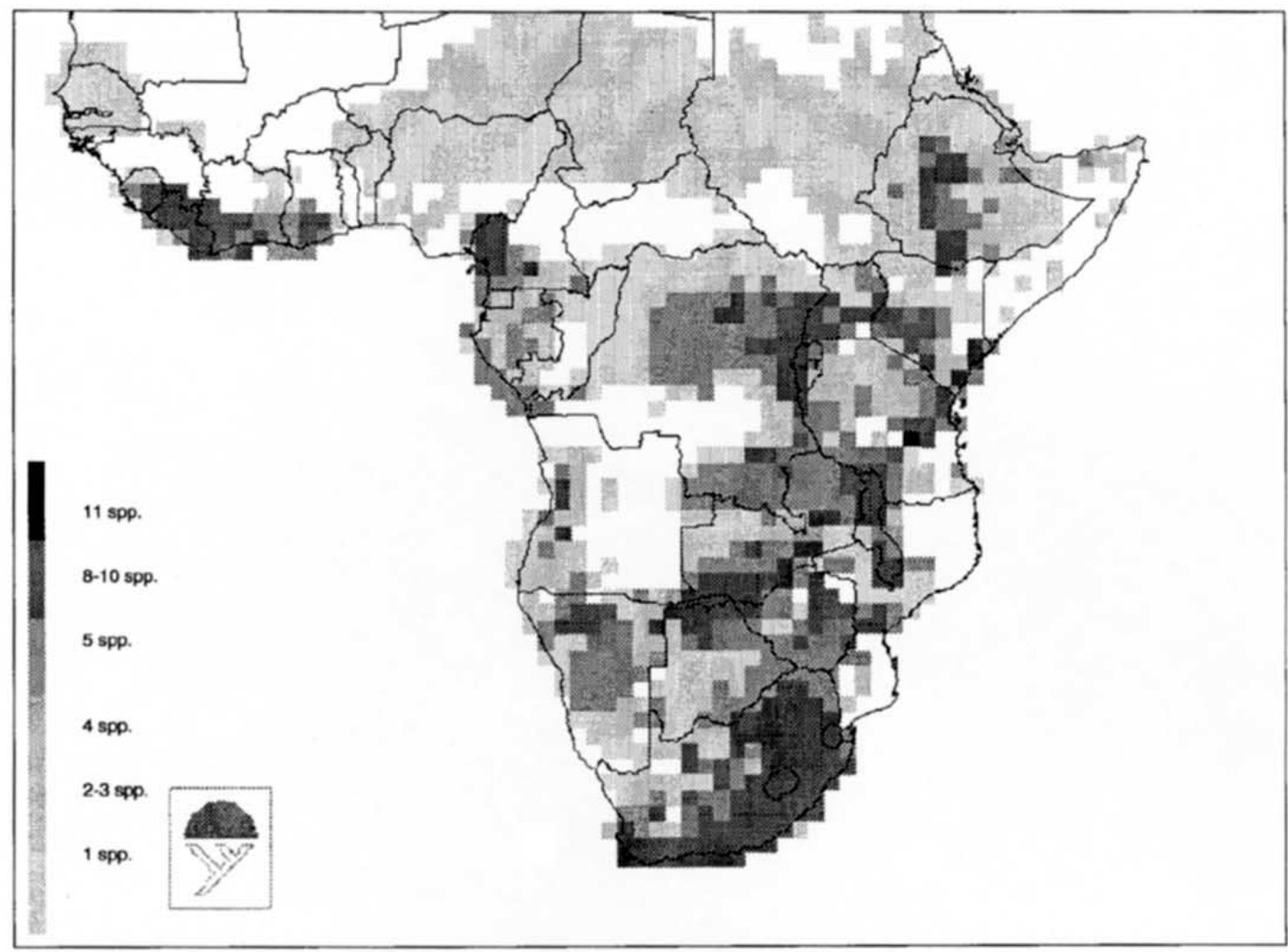

(ii)

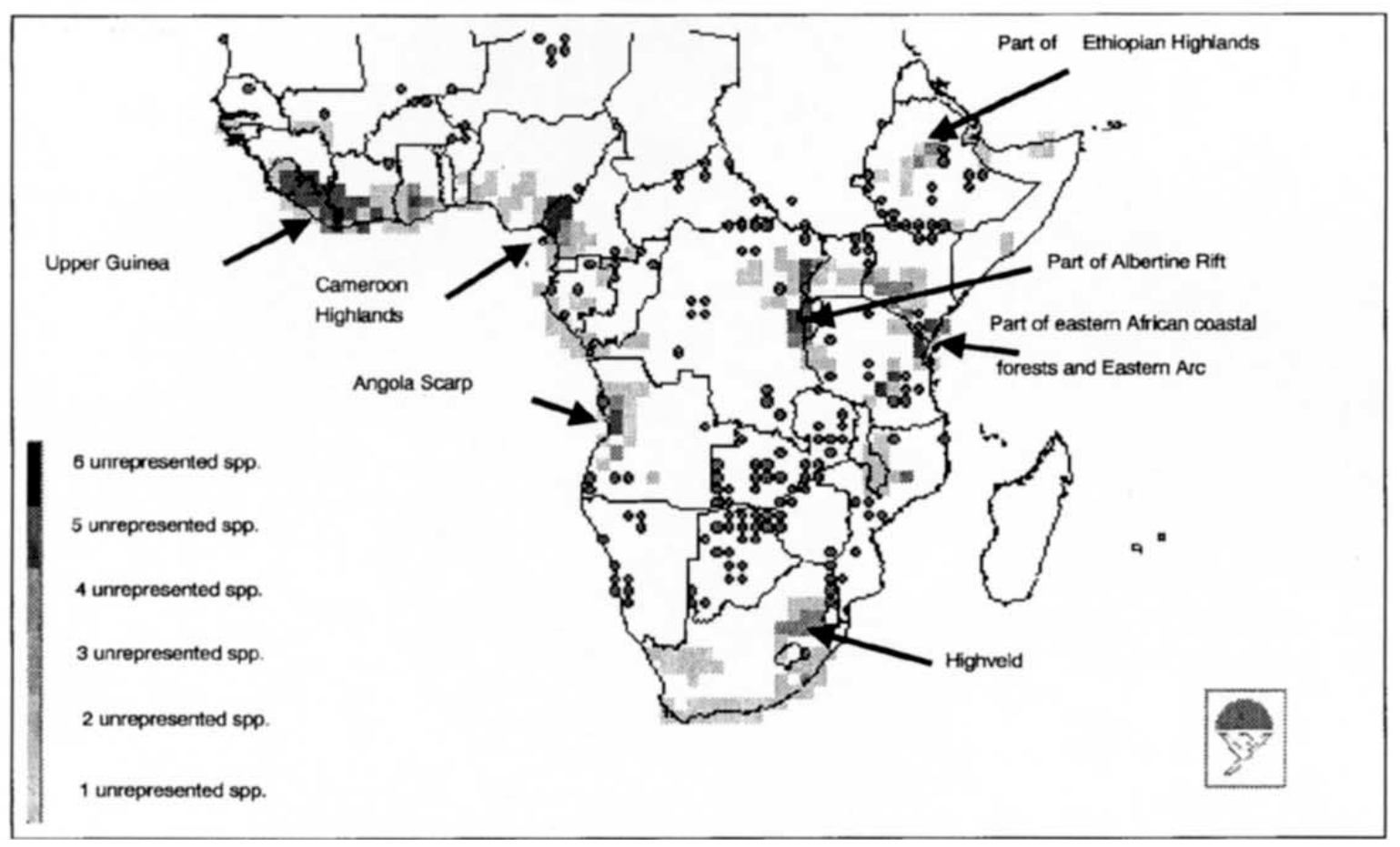


(iii)

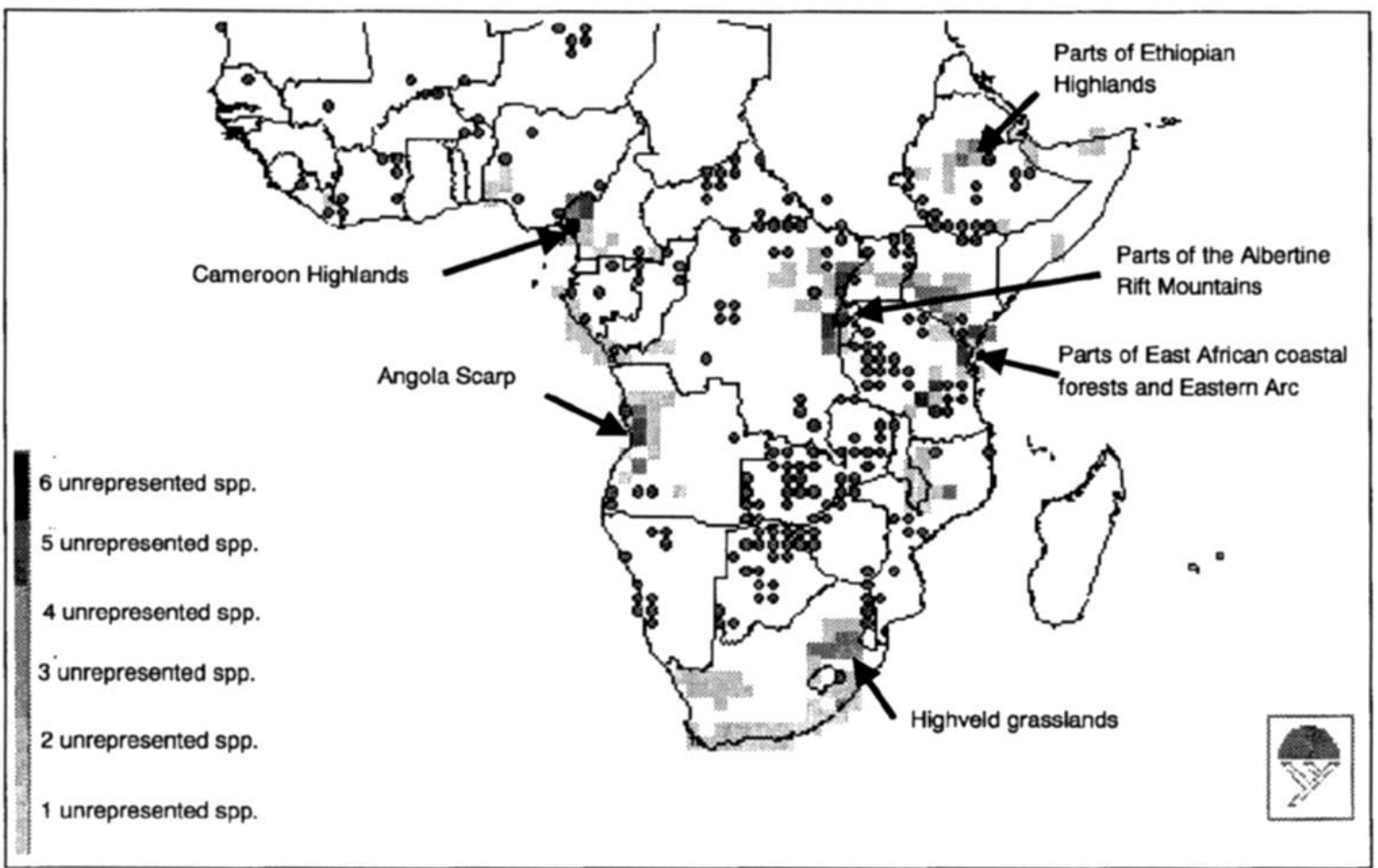

Fig. 3. (i) Patterns of richness of 106 threatened bird species across the Afrotropical region, (ii) gaps in species richness of threatened bird species not covered by grid cells defined as wildlife reserves, and (iii) wildlife plus forest reserves across the Afrotropical region. Dots represent 'protected' grid cells where at least $33 \%$ of the grid cell is covered by wildlife or forest reserves, and species richness is shaded from highest values in dark grey to lowest values in light grey. 
(i)

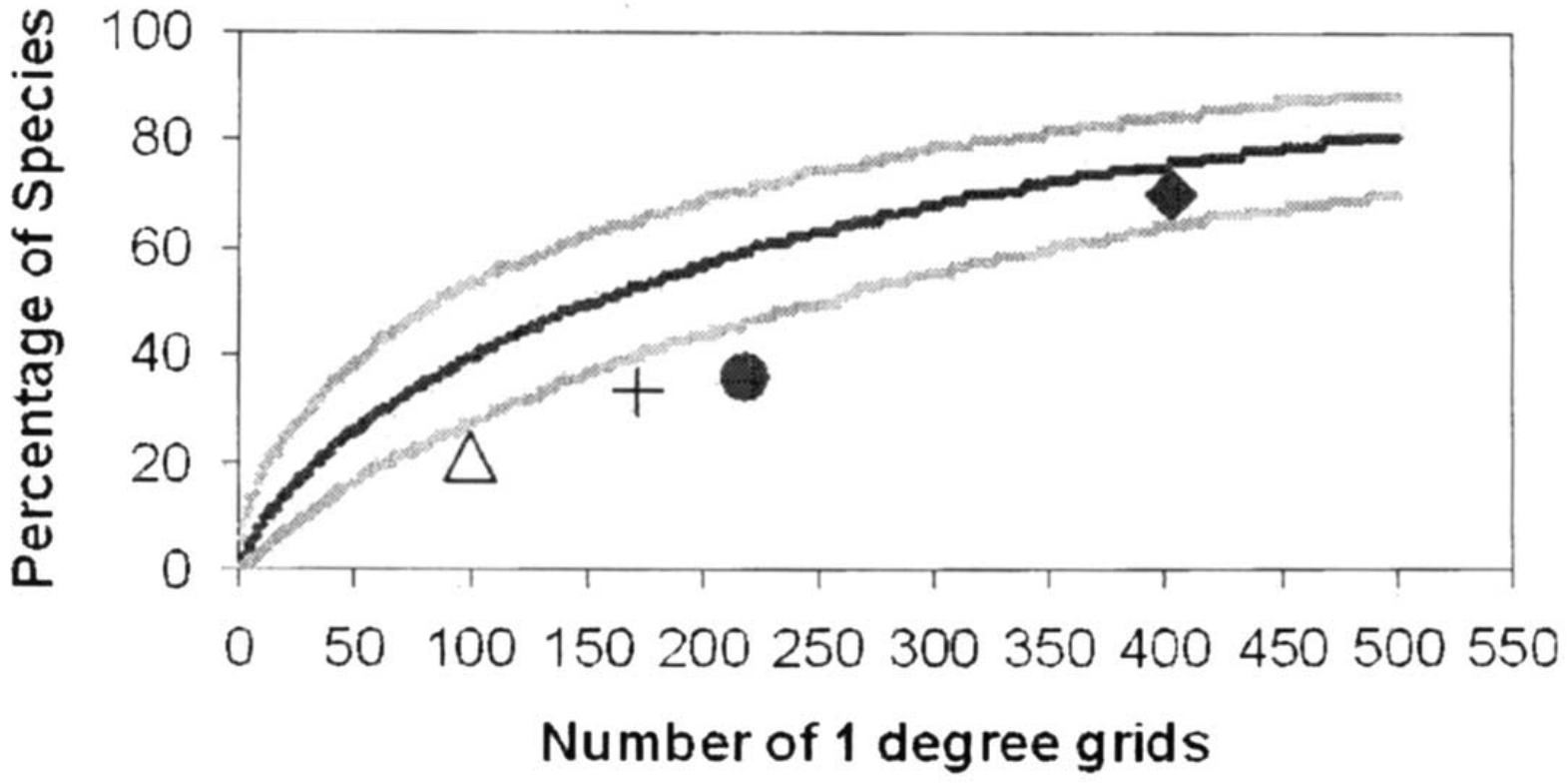

(ii)

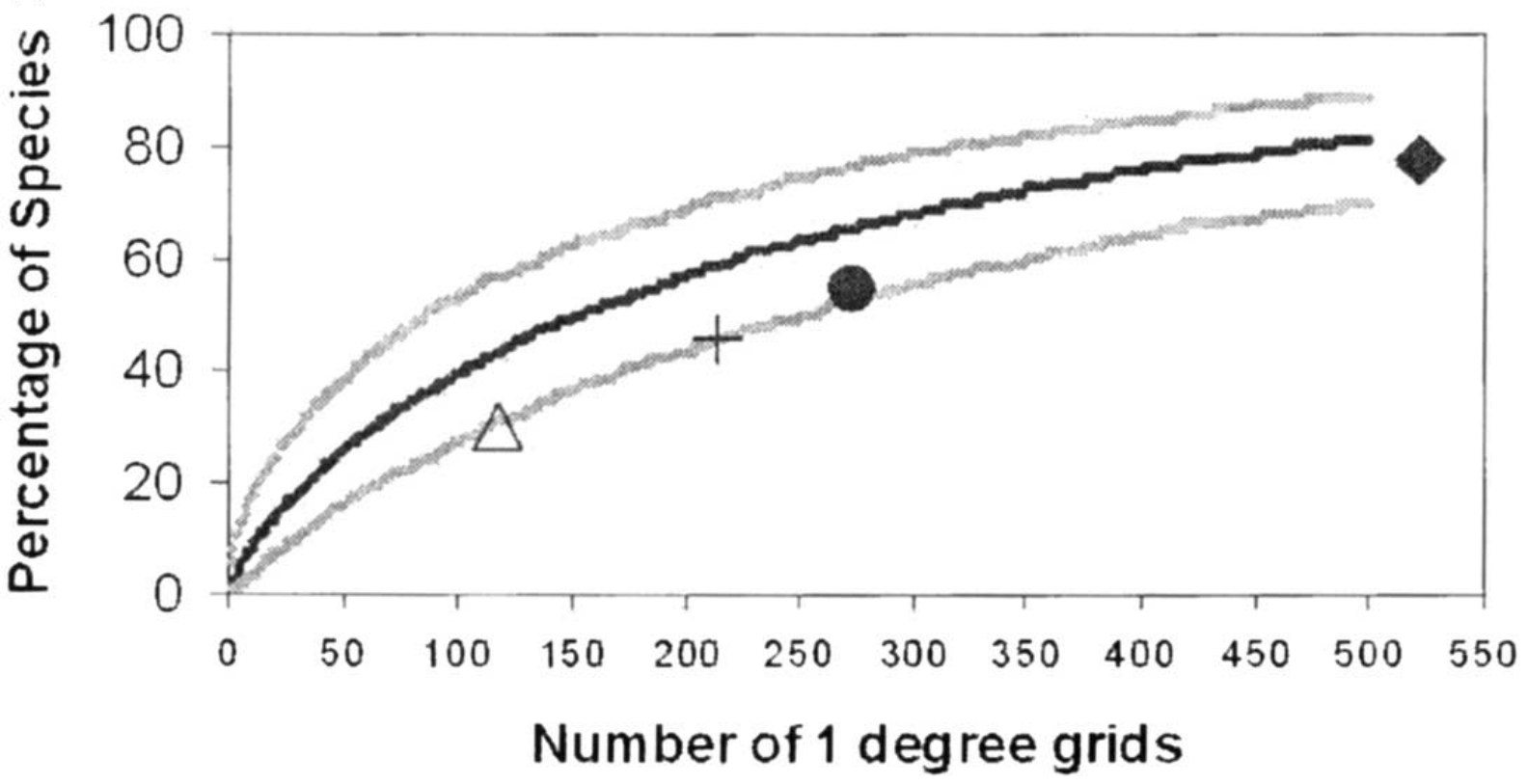

Fig. 4. Efficiency of (i) wildlife reserves and (ii) wildlife plus forest reserves in representing threatened bird species of sub-Saharan Africa relative to an idealised near-minimum set of areas selected at random. In both graphs the species representation in a near-minimum set is shown by the black line (with confidence intervals in grey). The solid diamond represents those grid cells with $>10 \%$ protected, the closed black circle those with $>25 \%$ protected, the open cross those with $>33 \%$ protected, and the open triangle those with $>50 \%$ protected. 